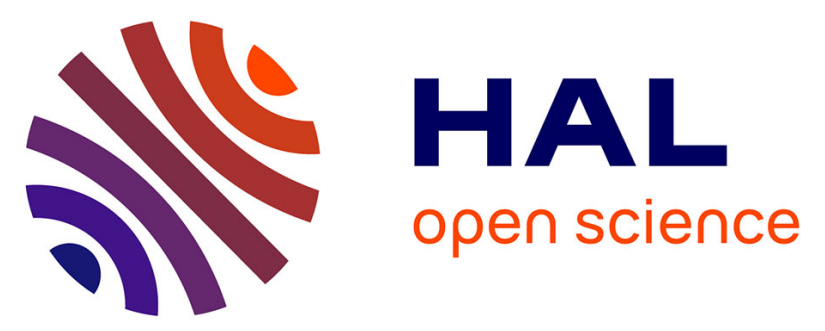

\title{
Comparison of two enzymatic immunoassays, high resolution mass spectrometry method and radioimmunoassay for the quantification of human plasma histamine
}

\author{
Caroline Poli, Mathieu Laurichesse, Octavie Rostan, Delphine Rossille, \\ Pascale Jeannin, Martine Drouet, Gilles Renier, Alain Chevailler, Karin Tarte, \\ Claude Bendavid, et al.
}

\section{- To cite this version:}

Caroline Poli, Mathieu Laurichesse, Octavie Rostan, Delphine Rossille, Pascale Jeannin, et al.. Comparison of two enzymatic immunoassays, high resolution mass spectrometry method and radioimmunoassay for the quantification of human plasma histamine. Journal of Pharmaceutical and Biomedical Analysis, 2016, 118, pp.307-314. 10.1016/j.jpba.2015.11.001 . hal-01231429

HAL Id: hal-01231429

https://hal-univ-rennes1.archives-ouvertes.fr/hal-01231429

Submitted on 25 Jan 2016

HAL is a multi-disciplinary open access archive for the deposit and dissemination of scientific research documents, whether they are published or not. The documents may come from teaching and research institutions in France or abroad, or from public or private research centers.
L'archive ouverte pluridisciplinaire HAL, est destinée au dépôt et à la diffusion de documents scientifiques de niveau recherche, publiés ou non, émanant des établissements d'enseignement et de recherche français ou étrangers, des laboratoires publics ou privés. 


\section{COMPARISON OF TWO ENZYMATIC IMMUNOASSAYS, HIGH RESOLUTION MASS SPECTROMETRY METHOD AND RADIOIMMUNOASSAY FOR THE QUANTIFICATION OF HUMAN PLASMA HISTAMINE}

Running head: Method comparison for human histamine quantification

\section{Caroline Polii,b,c*, Mathieu Laurichesse ${ }^{\mathrm{d}, \mathrm{e} *}$, Octavie Rostan ${ }^{\mathrm{d}}$, Delphine Rossille $\mathrm{e}^{\mathrm{f}}$, Pascale Jeannin $^{\text {a,b,c, }}$, Martine Drouet ${ }^{\mathrm{g}}$, Gilles Renierc ${ }^{\mathrm{c}}$, Alain Chevailler ${ }^{\mathrm{a}, \mathrm{b}, \mathrm{c}}$, Karin Tarte $^{\mathrm{d}, \mathrm{h}, \mathrm{i}}$, Claude Bendavid ${ }^{\mathrm{e}, \mathrm{h}, \mathrm{j}}$, Céline Beauvillaina ${ }^{\mathrm{a}, \mathrm{b}, \mathrm{c} * *}$, Patricia Amé-Thomas $^{\mathrm{d}, \mathrm{h}, \mathrm{i} * *}$}

${ }^{a}$ Université d'Angers, Angers, Faculté de Médecine, 49100 Angers, France

${ }^{b}$ INSERM, Unit 892, 49100 Angers, France; CNRS, Unit 6299, Angers, France; LabEx IGO "ImmunoGraft Oncology", France

${ }^{c}$ CHU Angers, Laboratoire d'Immunologie et d'Allergologie, Pôle Biologie, 49100 Angers, France

d CHU Rennes, Laboratoire d'Immunologie, Thérapie Cellulaire et Hématopoïèse, Pôle Biologie, 35033 Rennes, France

${ }^{e}$ CHU Rennes, Laboratoire de Biochimie, Pôle Biologie, 35033 Rennes, France

${ }^{f}$ CHU Rennes, Laboratoire d'Hématologie, Pôle Biologie, 35033 Rennes, France

${ }^{g}$ CHU Angers, Unité d'Allergologie générale. Département de Pneumologie, 49100 Angers, France

${ }^{h}$ Université de Rennes 1, Faculté de Médecine, 35043 Rennes, France

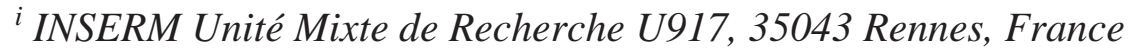

${ }^{j}$ INSERM, Unité Mixte de Recherche U991, 35043 Rennes, France

Correspondence:

Céline Beauvillain

Laboratoire d'Immunologie et d'Allergologie

Institut de Biologie en Santé (PBH) - CHU d'Angers

4, Rue Larrey

49933 ANGERS Cedex 09

celine.beauvillain@chu-angers.fr

Patricia Amé-Thomas

Laboratoire d'Immunologie, Thérapie Cellulaire et Hématopoïèse

Pôle Biologie - Hôpital Pontchaillou

2 Avenue du Pr Léon Bernard

35033 RENNES Cedex

patricia.ame-thomas@chu-rennes.fr

* C.P. and M.L. contributed equally to this work

** C.B. and P.A.T. contributed equally to this work and are co-corresponding authors 


\section{Graphical abstract}
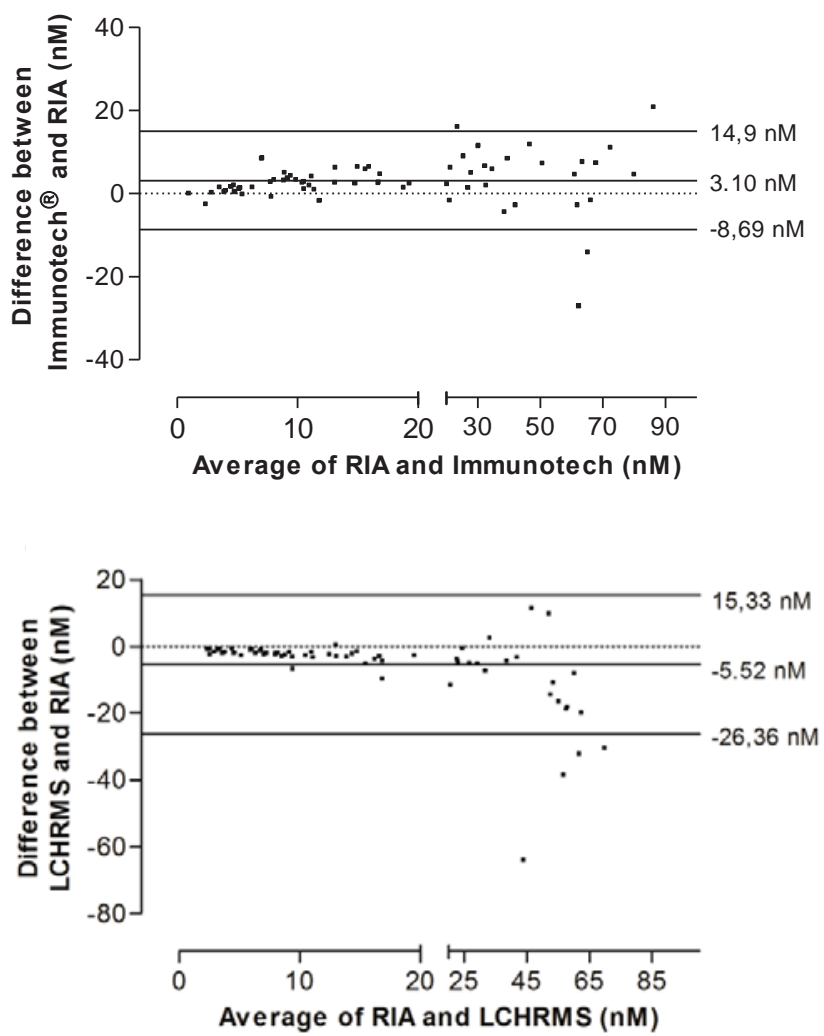


\section{Highlights}

- $\quad$ LCHRMS and Immunotech ${ }^{\circledR}$ EIA both displayed high correlation with RIA

- LCHRMS displayed high sensitivity and specificity

- $7.88 \mathrm{nM}$ and $14.39 \mathrm{nM}$ was determined as new cut-offs for LCHRMS and Immunotech ${ }^{\circledR}$ EIA 


\section{ABSTRACT}

Histamine (HA) is one of the main immediate mediators involved in allergic reactions. HA plasma concentration is well correlated with the severity of vascular and respiratory signs of anaphylaxis. Consequently, plasma quantification of HA is useful to comfort the diagnosis of anaphylaxis. Currently, radioimmunoassay (RIA) is the gold standard method to quantify HA due to its high sensitivity, but it is time consuming, implicates specific formations and cautions for technicians, and produces hazardous radioactive wastes. The aim of this study was to compare two enzymatic immunoassays (EIA) and one in-house liquid chromatography high-resolution mass spectrometry method (LC-HRMS) with the gold standard method for HA quantification in plasma samples of patients suspected of anaphylaxis reactions. Ninetytwo plasma samples were tested with the 4 methods (RIA, 2 EIA and LC-HRMS) for HA quantification. Fifty-eight samples displayed HA concentrations above the positive cut-off of $10 \mathrm{nM}$ evaluated by RIA, including 18 highly positive samples (> $100 \mathrm{nM})$. Our results showed that Immunotech ${ }^{\circledR}$ EIA and LC-HRMS concentrations were highly correlated with RIA values, in particular for samples with a HA concentration around the positive cut-off. In our hands, plasma concentrations obtained with the Demeditec Diagnostics ${ }^{\circledR}$ EIA correlated less with results obtained by RIA, and an underestimation of plasma HA levels led to a lack of sensitivity. In conclusion, this study demonstrates that Immunotech $^{\circledR}$ EIA and LC-HRMS method could be used instead of RIA to assess plasma HA in human diagnostic use.

\section{ABBREVIATIONS}

EIA: enzymatic immunoassay

HA: histamine

LC-HRMS: liquid chromatography high resolution mass spectrometry

RIA: radioimmunoassay

Keywords: enzymatic immunoassay, histamine, mass spectrometry, radioimmunoassay 


\section{INTRODUCTION}

Anaphylaxis is a potentially lethal systemic type I hypersensitivity reaction [1]. This lifethreatening emergency can lead very quickly to hypovolemia shock and cardiorespiratory arrest. In western countries, anaphylaxis incidence is estimated to be comprised between 4 and 50/100000 inhab/year with a prevalence of 0.05-2\%. Emergency admission registers highlight a two fold increase of anaphylaxis prevalence during the last decades [2].

After a first exposure to an allergen leading to high-affinity $\operatorname{IgE}$ synthesis by long-lived plasma cells, these IgE are predominantly found linked to the high-affinity IgE receptor (FceRI) at the cell surface of mast cells and basophils. Following a second exposure to the same allergen, the cross-linking of the FceRI leads to cell activation and the release within a few minutes of a huge amount of histamine (HA) contained in cell granules $\left(10^{-5}\right.$ to $10^{-3}$ $\mathrm{mol} / \mathrm{L})[3,4]$, as well as other preformed proinflammatory mediators [5]. HA or 2-(1Himidazol-4-yl) ethanamine is synthetized from L-histidine in the Golgi apparatus by the histidine decarboxylase [6]. Several cell types can synthetize HA in humans [7], but mast cells and basophils distinguish themselves by their ability to store HA in their granules, enabling a huge acute release of HA upon IgE cross-linking.

The anaphylaxis diagnosis is usually retained on a body of evidence. Suspicion is made primarily on clinical signs [8-10]. Currently, two biological parameters are commonly used to strengthen the diagnosis of anaphylaxis: serum tryptase and plasma HA. HA quantification is useful to confirm that clinical signs result from the degranulation of mast cells and/or basophils [11]. Physiologically, basal plasma HA amount is very low $(<10 \mathrm{nM})$ [8] but can increase very quickly and exponentially after mast cell or basophil degranulation. Nevertheless, the HA protein half-life is extremely short [12]. Consequently, strict procedures of sampling for HA quantification are required: blood collection must be conducted within 15-60min after the beginning of the symptoms and plasma isolation has to be performed very 
quickly before conservation [13]. The production of highly specific monoclonal antibodies targeting $\mathrm{HA}$ is extremely challenging due to the nature of this small biogenic amine $\left(\mathrm{M}=111 \mathrm{~g} \cdot \mathrm{mol}^{-1}\right)$. The former quantification assays were based on the covalently binding of HA to a carrier protein on imidazole core or on $\mathrm{NH}_{2}$ end; nevertheless this chemical process was difficult to apply on plasma samples. Currently, classical HA quantification assays used for in vitro diagnosis (IVD) and based either on radioimmunoassay (RIA) [14] or enzymatic immunoassay (EIA) methods include an acylation step with NOH succinimide ester succinyl glycinamide, which turns HA into a bigger and more stable molecule that becomes easily detectable. Acylated plasma HA competes with exogenous acylated HA conjugated with a radioelement or an enzyme to bind a highly specific monoclonal antibody [15]. The current gold standard for HA quantification is RIA, it has the advantage of being highly sensitive [14], but requires the use of radioactive reagents implying the formation and the follow up of the technicians, as well as the dangerous and expensive waste management. More recently, two EIA kits for IVD use, both avoiding the use of radioelements, have been commercialized by Immunotech $^{\circledR}$ and Demeditec Diagnostics ${ }^{\circledR}$. Finally, some methods using mass spectrometry have been developed to quantify plasma HA $[16,17]$. In particular, our team developed an in-house plasma HA quantification assay for diagnostic use based on high Resolution Accurate Mass LC-MS (LC-HRMS) technology [18]. The LC-HRMS method is known to be highly sensitive and specific, averts radioactivity use, and avoids the potential detection of the metabolites of the targeted protein.

In this study, HA concentration was assessed in human plasma collected from patients with suspected anaphylactic reaction using three different methods: the gold standard RIA, the two commercialized EIA kits, and the in-house LC-HRMS-based method. This comparison reveals that Immunotech ${ }^{\circledR}$ EIA and LC-HRMS are both sensitive enough methods to be considered as relevant non-radioactive alternative methods to RIA. 


\section{MATERIALS AND METHODS}

\subsection{Plasma samples}

Plasmas collected between February 2010 and February 2014 in routine clinical practice by laboratories of Angers and Rennes University Hospitals from patients following a suspected anaphylaxis reaction were tested for HA quantification. The Ethical Review Board in Angers approved this study (2015/40). Peripheral blood was collected by venipuncture in EDTA tubes, and plasma was separated by centrifugation at $3000 \mathrm{~g}$ for $10 \mathrm{~min}$. Thereafter, plasma was aspirated gently while respecting a safety margin of $1 \mathrm{~cm}$ from the buffy coat in order to avoid contamination by white blood cells, aliquoted and immediately frozen at $-20^{\circ} \mathrm{C}$.

\subsection{Radioimmunoassay}

HA quantification by RIA was performed following manufacturer's instructions (Immunotech, Marseille, France). Briefly, immediately after thawing, HA contained in plasma samples was acylated. Then, plasma samples were incubated overnight within monoclonal antibody $(\mathrm{mAb})$-coated tubes in presence of a ${ }^{125}$ I-labeled acylated HA internal tracer. Following incubation, the contents of the tubes were aspirated and bound radioactivity was measured using a Cobra 2 auto gamma counter (Packard instrument, Meriden, CT, USA) . Limits of quantification given by the manufacturer were $0.2-100 \mathrm{nM}$. The limit for pathological values is $10 \mathrm{nM}$.

\subsection{Enzymatic immunoassays}

HA quantification by EIA was performed following manufacturers' recommendations (Immunotech ${ }^{\circledR}$ and Demeditec Diagnostics ${ }^{\circledR}$, Kiel, Germany). For both kits, samples were manipulated in polypropylene tubes and tested in duplicate. 
For Immunotech ${ }^{\circledR}$ EIA, HA was acylated by a first vortex step with an acylation reagent. Acylated control, standard and plasma solutions were further incubated in mAb-coated wells in presence of alkaline phosphatase acylated HA for 2 hours at $2-8^{\circ} \mathrm{C}$ under shaking (350rpm). After incubation, wells were rinsed with a microtiter plate washer in order to remove non-bound components. The remaining enzymatic activity was then measured at $405 \mathrm{~nm}$ after the addition of a chromogenic substrate. A quadratic polynomial equation was used to define the standard curve; the correlation coefficient $r$ was always $>0.993[0.987$ 0.999], and the median control values were 5.561 [95\% CI 5.459-5.660] nM for theoretical value between 5.00 and 7.40nM. Standard curve included dilutions from 1.00 to $100 \mathrm{nM}$ of HA, as recommended. Limits of quantification given by the manufacturer were $0.50-100 \mathrm{nM}$.

For Demeditec Diagnostics ${ }^{\circledR}$ EIA, HA was acylated by incubation with an acylating reagent for $45 \mathrm{~min}$ at room temperature $(\mathrm{RT})$ on a shaker $(600 \mathrm{rpm})$ and further competed with plasticcoated HA for a precise amount of HA antibody binding sites added into the well. Equilibrium of the system was reached after 3 hours at RT $\left(20-25^{\circ} \mathrm{C}\right)$ on a shaker (approximately 600rpm). Then, free antibody and plasma HA-antibody complexes were removed by washing. The antibodies conjugated with plastic-coated HA were detected by a peroxidase-conjugated anti-rabbit IgG using tetramethylbenzidine as substrate. The reaction was monitored at $450 \mathrm{~nm}$. A quadratic polynomial equation was used to define the standard curve, included standard concentrations between 4.5 and $450 \mathrm{nM}$ of HA, as recommended. The correlation coefficient $r$ was always $>0.99[0.992-1.000]$. The median control values were 26.1nM [22.0-33.7] and $80.4 \mathrm{nM}$ [60.6-102.5] for theoretical values of 30.0 and $100.0 \mathrm{nM}$, respectively. The manufacturer gave no target range of concentration for the controls. Limits of quantification given by the manufacturer were $6.6-76.0 \mathrm{nM}$. 


\subsection{High Resolution Accurate Mass LC-MS technology}

A liquid chromatography coupled with an ultra-high resolution and accurate mass instrument was used to determine HA concentration. Briefly, $100 \mu \mathrm{L}$ of plasma was added to $250 \mu \mathrm{L}$ of de-ionized water and $100 \mu \mathrm{L}$ of internal standard Histamine-d4 (HAd4) $(\mathrm{C} / \mathrm{D} / \mathrm{N}$ isotopes, Quebec, Canada). Sulfosalicylic acid $(50 \mu \mathrm{L}$ at 20\% v/v) (Sigma-Aldrich, Saint-Louis, MO, USA) was added for protein precipitation. After centrifugation at $3000 \mathrm{~g}$ for $10 \mathrm{~min}$ at $4{ }^{\circ} \mathrm{C}$, $200 \mu \mathrm{L}$ of supernatant were transferred to an auto-sample vial before analysis. Separation of the analytes was achieved on a C18 Accucore column (100 mm x 2.1, 2.6 $\mu \mathrm{m})$ (Thermo Scientific, San José, CA, USA) using a gradient run with solvant A (nonafluoropentanoic acid $3 \mathrm{mM}$ ) and solvent B (acetonitrile-formic acid 0.1:100, v/v) formic acid). The analytes were detected using a Q Exactive ${ }^{\mathrm{TM}}$ (Thermo Scientific) mass spectrometer operating in positive electrospray ionisation. In full scan mode, the exact mass of each protonated species (112.0869 for HA; 116.1120 for HAd4) was extracted for quantification; one ion transition was monitored per compound for quantification in fragmentation mode (HA: 112.0869 $>95.0607 \mathrm{~m} / \mathrm{z}$; and HAd4: $116.1120>99.0855 \mathrm{~m} / \mathrm{z}$ ). The calibration curve for HA in plasma was linear from 1 to $100 \mathrm{nM}$.

\subsection{Statistical analysis}

Sensitivity (Se), specificity (Sp), positive predictive value (PPV) and negative predictive value (NPV) of EIA and LC-HRMS were calculated and compared to RIA. A threshold of $10 \mathrm{nM}$ was used, because $10 \mathrm{nM}$ is considered the classical admitted limit for pathological values [8], and corresponds to the cut-offs given by manufacturers for RIA and EIA kits. Then, the analyses were restricted to the samples with HA measures comprised within the quantification limits of the two methods. HA concentrations measured by LC-HRMS, and Immunotech $^{\circledR}$ and Demeditec Diagnostics ${ }^{\circledR}$ EIA were compared using Pearson correlation 
coefficient with concentrations obtained with RIA. Bland-Altman tests were performed to evaluate the agreement of each method versus RIA. Bias and $95^{\text {th }}$ limits of agreement (LOA, average difference $\pm 1.96 \mathrm{SD}$ of the difference) were calculated. Samples with a RIAmeasured HA concentration comprised between 1 and $20 \mathrm{nM}$ were further specifically investigated, because this range of concentrations could be delicate to interpret by the clinicians, and must be interpreted together with the severity of the symptoms and the results of additional biological tests, in order to conclude to anaphylaxis. Finally, receiver operating characteristic (ROC) curves were used to determine the new cut-off values for EIA Immunotech ${ }^{\circledR}$ and LC-HRMS methods; the optimal cut-off point being the threshold that maximizes the sum of the sensitivity and the specificity (Youden's index). GraphPad Prism 5.0 (GraphPad software, San Diego, CA, USA), Excel and Stata (College Station, TX, USA) softwares were used.

\section{RESULTS AND DISCUSSION}

\subsection{Cohort recruitment and HA quantification by RIA}

This study aimed to compare HA concentrations of human plasma samples from patients with suspected anaphylactic reaction quantified with several assays for in vitro diagnostic use. HA measurement for 34 samples (37\%) was quantified below the threshold of 10nM by RIA, and was consequently considered negative in routine clinical practice. One of these 34 samples was quantified below $0.2 \mathrm{nM}$ corresponding to the RIA lower limit of detection. Fifty-eight samples $(63 \%)$ were considered positive with HA concentration measured by RIA above 10nM, including 18 samples with a concentration above the RIA upper limit of quantification of 100nM. Globally, HA concentrations of our cohort of 92 samples were well distributed over the quantification range of the RIA. The RIA method remains the historical gold standard for HA quantification in biologic fluids since several decades. Despite its high 
sensitivity (analytical sensitivity: $0.2 \mathrm{nM}$ ), this radioactive method displays several disadvantages, including the exposition risk of technicians to ${ }^{125} \mathrm{I}$ and the management of radioactive wastes. Furthermore, the use of the radioactive reagents restricted to a specific window of radioactive decay leads to peculiar ordering of reagents, increases the delay of reagent shipment, and consequently expands the waiting time of results for the patient. We selected 3 alternative assays using 2 different methods: Immunotech ${ }^{\circledR}$ EIA, Demeditec Diagnostics ${ }^{\circledR}$ EIA and LC-HRMS (Table S1) $[18,19]$. HA concentration values obtained by RIA were compared with the HA concentrations obtained with each of the other methods, based on a list of samples presenting a HA concentration in the detection limits of both tested methods.

\subsection{Comparison of Immunotech ${ }^{\circledR}$ EIA to RIA}

HA concentration of the 92 tested samples was evaluated with RIA and Immunotech ${ }^{\circledR}$ EIA. Considering all samples, sensitivity of the Immunotech ${ }^{\circledR}$ EIA method was $100 \%$ with no false negative, and the specificity was 59\% (table 1). Indeed, 14 false positive results were obtained with the Immunotech ${ }^{\circledR}$ EIA method with HA quantification values comprised between 11 and 16nM. Comparing HA concentrations measured with the 2 methods, a maximal difference of 8.6nM for 2 samples was obtained. Finally, the positive and negative predictive values were $81 \%$ and $100 \%$, respectively (table 1 ).

Among the 92 samples from our cohort, 91 were within the detection limits of RIA. Among the 91 samples, $72(79 \%)$ were between 0.5 and $100 \mathrm{nM}$, the detection limits of Immunotech ${ }^{\circledR}$ EIA. We therefore decided to only compare these 72 selected samples, and calculated a Pearson's correlation coefficient $r$ of $0.96(95 \%$ CI $0.94-0.98 ; p<0.0001)$ for this sample set (figure 1A). The Bland-Altman plot comparing Immunotech ${ }^{\circledR}$ EIA to RIA values showed an 
estimated bias of 3.10nM (SD: $6.02 \mathrm{nM}$; 95\% limits of agreement: $-8.69-14.90 \mathrm{nM}$ ) (figure 1B).

Because HA concentrations between 1 and $20 \mathrm{nM}$ could be arduous to interpret for clinicians [20], a focus was made on samples displaying concentrations measured by RIA comprised in this range $(\mathrm{n}=47)$, and a Pearson's correlation coefficient of 0.88 (95\% CI $0.80-0.93$; $\mathrm{p}<0.0001$ ) was calculated (Figure 1C). The subsequent Bland-Altman plot showed an estimated bias of $+2.97 \mathrm{nM}$ (SD: 3.08nM; 95\% limits of agreement: $-3.07-9.01 \mathrm{nM}$ ) (table 2). Globally, Immunotech ${ }^{\circledR}$ EIA and RIA values were well correlated even if a slight overestimation of HA concentration using Immunotech $^{\circledR}$ EIA was observed. Of note, Immunotech $^{\circledR}$ EIA kit has been developed by the same manufacturer and shares with the RIA kit most of the reagents. Essentially only the revelation step $\left({ }^{125}\right.$ I-labeled histamine tracer versus histamine-phosphatase alkaline conjugate) is different. Interestingly, EIA methods avoid staff exposition to radiation hazards, are easy to perform, and do not require specifically trained staff, unlike RIA methods. Moreover, equipment needed is inexpensive and widely available.

In conclusion, besides a slight overestimation of HA concentrations, all these observations support the hypothesis that EIA can be a favorable alternative to RIA, as described previously for other molecules like progesterone, cortisol, or infliximab [21-23].

\subsection{Comparison of Demeditec Diagnostics ${ }^{\circledR}$ EIA to RIA}

For the 92 plasma samples tested, no false positive were found resulted in $100 \%$ specificity for Demeditec Diagnostics EIA versus RIA. Nevertheless, 20 false negative values were observed leading to a sensitivity of $66 \%$ (table 1 ).

Among the 91 samples within the detection limits of RIA, only 23 plasma samples $(25 \%)$ were between 6.66 and $76 \mathrm{nM}$, the limits of detection of Demeditec Diagnostics ${ }^{\circledR}$ EIA, and 
were further compared to RIA. The Pearson's correlation coefficient $r$ calculated for the 23 samples was 0.45 (95\% CI: 0.05-0.73; $\mathrm{p}=0.0311)$ (figure 2A). As shown in the Bland-Altman plot, HA quantification was underestimated with Demeditec Diagnostics ${ }^{\circledR}$ EIA with a mean difference of -17.85nM (SD: 20.16nM; 95\% limits of agreement: -57.36 - 21.66nM) (figure 2B). Finally, only 4 samples quantified between 1 and $20 \mathrm{nM}$ by RIA were in the limits of quantification of Demeditec Diagnostics ${ }^{\circledR}$ EIA kit, so it was not judicious to specifically focus on these samples.

In conclusion, in our hands, the use of Demeditec Diagnostics ${ }^{\circledR}$ EIA resulted in an important proportion of false negative samples, which could be an obstacle for the diagnosis of anaphylaxis. A poor correlation with RIA values was obtained, despite excellent correlation coefficients obtained for the standard curves built with 5 standard dilutions $(r>0.99)$. Comparing Demeditec Diagnostics ${ }^{\circledR}$ EIA, Immunotech ${ }^{\circledR}$ EIA and RIA protocols, we noticed a longer acylation step for Demeditec Diagnostics ${ }^{\circledR}$ EIA (45min versus an immediate acylation by vortexing for the 2 other assays). This could explain the important underestimation of HA quantification for the Demeditec Diagnostics ${ }^{\circledR}$ EIA method, because it is well known that HA remains stable only after acylation.

\subsection{Comparison of LC-HRMS to RIA}

For the 92 plasma samples tested, LC-HRMS sensitivity was $93 \%$ with 4 false negatives, and specificity was $100 \%$ with no false positive. The PPV and NPV were $100 \%$ and $89 \%$, respectively (table 1).

Seventy-one of the 92 tested plasma samples showed HA concentrations comprised within the limits of quantification of the 2 methods. The Pearson's correlation coefficient $r$ calculated on the 71 samples was 0.90 (95\% CI 0.84-0.94; $\mathrm{p}<0.0001)$ (figure 3A). Bland-Altman plot showed an underestimation of the LC-HRMS method (bias: $-5.52 \mathrm{nM}$; SD: $10.64 \mathrm{nM}$; 95\% 
limits of agreement: $-26.36-15.33 \mathrm{nM}$ ) (figure 3B). When considering the 46 samples with a HA quantification comprised between 1 and 20nM by RIA, LC-HRMS results remained highly correlated to those obtained using RIA (Pearson's correlation coefficient $r=0.97 ; 95 \%$ CI: $0.95-0.98 ; \mathrm{p}<0.0001$ ) (figure $3 \mathrm{C}$ ), and a mean difference of $-1.94 \mathrm{nM}$ (SD: 1.26nM; 95\% limits of agreement: $-4.41-0.53 \mathrm{nM}$ ) was obtained for the Bland-Altman analysis (table 2). At this same range, Immunotech ${ }^{\circledR}$ EIA was weakly correlated with a correlation coefficient of 0.88 , was still very sensitive, but display many false positive results that could lead to overdiagnosis (Figure 1C).

In conclusion, besides a slight underestimation of HA concentrations measured by LCHRMS, LC-HRMS gave particularly encouraging results, as a good correlation with RIA was found [18].

\subsection{Comparison of the 3 tested assays to RIA}

The 4 tested assays display similar characteristics with respect to their lower limit of quantification and their quantification range, except for the Demeditec Diagnostics ${ }^{\circledR}$ EIA which display a lower limit of quantification (LLOQ) of $6.66 \mathrm{nM}$, close to the positive threshold of 10nM. Our results highlight a very high sensitivity for Immunotech ${ }^{\circledR}$ EIA and LC-HRMS (100\% and 93\%, respectively), in contrast to Demeditec Diagnostics ${ }^{\circledR}$ EIA (66\%). This latter assay showed 20 false negative among the 58 samples considered as positive with a threshold of 10nM. Among these 20 false negative results, RIA quantified 3 of them as having a concentration higher than 70nM. Demeditec Diagnostics ${ }^{\circledR}$ EIA and LC-HRMS showed a perfect specificity (1.00 for both), compared to RIA. A high number of false positives were found for Immunotech ${ }^{\circledR}$ EIA (14 out of 72 positive samples), but the mean HA concentration of these samples was $11.91+/-1.40 \mathrm{nM}$, which represent concentrations close to the positive threshold of $10 \mathrm{nM}$. 
It is well known that $\mathrm{HA}$ is very quickly metabolized in vivo by the histamine $\mathrm{N}$ methyltransferase (HNMT) and the diamine oxydase (DAO) with a short half-life estimated at 102 seconds (17). A degradation of HA for a specific test can be rule out, as samples for each assay were aliquoted and frozen simultaneously. Thawing procedure in ice was also the same for the 4 assays. According to the manufacturers' data, cross-reactivity with the metabolite methyl histamine is estimated at $0.1 \%$ in Demeditec Diagnostics ${ }^{\circledR}$ EIA, and cross-reactivity to acylated methyl histamine is estimated at $0.027 \%$, and $0.069 \%$ in Immunotech ${ }^{\circledR}$ EIA and RIA, respectively. LC-HRMS is the only assay that can distinguish methyl histamine from HA [1618]. This could explain the trend of LC-HRMS to slightly underestimate plasma HA concentrations in comparison to RIA.

\subsection{New cut-offs for Immunotech ${ }^{\circledR}$ EIA and LC-HRMS assays}

At the sight of statistical results obtained with Immunotech EIA and LC-HRMS method, we decided to optimize the sensitivity and specificity of these 2 assays by determining new cutoffs. For this purpose, Ninety-two plasma samples have been used to build ROC curves in order to define new cut-offs for Immunotech EIA ${ }^{\circledR}$ kit and LC-HRMS method. Using the cutoff value of $10 \mathrm{nM}$ of HA after quantification with RIA, 58 plasma samples were classified as positive $(\geq 10 \mathrm{nM})$ and 34 as negative $(<10 \mathrm{nM})$. Considering HA concentrations obtained for Immunotech EIA ${ }^{\circledR}$, the area under the curve (AUC) was 0.990 , and with a cut-off value of $14.39 \mathrm{nM}$ (figure 4A), a sensitivity of $96.55 \%$ and a specificity of $97.06 \%$ was calculated. For LC-HRMS, the calculated AUC was 0.994 and the cut-off value was defined at $7.88 \mathrm{nM}$ with a sensitivity of $97.06 \%$ and a specificity of $98.28 \%$ (figure 4B). Using these new cut-offs and for the 92 tested samples, this allows minimizing the number of false positive samples from 14 to 1 for Immunotech EIA, and reducing the number of false negative from 4 to 1 for LCHRMS (table 3). 


\section{CONCLUSION}

Our results demonstrate that LC-HRMS and Immunotech ${ }^{\circledR}$ EIA could be good alternatives to RIA for HA quantification in medical laboratories, after optimization of the sensitivity and the specificity of the two assays using new cut-offs (7.88 and 14.39nM for LC-HRMS and Immunotech ${ }^{\circledR}$ EIA, respectively). These two methods have the advantage to avoid the use of radioactivity with all its constraints. However, rare are the laboratories possessing a highresolution mass spectrometer due to the price of the instruments, and this could limit the development of HA quantification with LC-HRMS.

\section{CONFLICT OF INTEREST STATEMENT}

The authors declare no conflict of interest.

\section{ACKNOWLEDGMENTS}

This work was supported by institutional grant from the "Fonds d'Innovation Interne" of the University Hospital of Rennes. We thank Laëtitia Huchet, Sabrina Couet and Séverine Gadras from the immunology laboratory of the University Hospital of Angers for their technical assistance. We thank the Allergobionet group (http://www.allergobionet.fr). 


\section{REFERENCES}

[1] P. Lieberman, R.A. Nicklas, J. Oppenheimer, S.F. Kemp, D.M. Lang, D.I. Bernstein, J.A. Bernstein, A.W. Burks, A.M. Feldweg, J.N. Fink, P.A. Greenberger, D.B. Golden, J.M. James, D.K. Ledford, A.L. Sheffer, J. Blessing-Moore, L. Cox, D.A. Khan, D. Lang, J.M. Portnoy, C. Randolph, D.E. Schuller, S.L. Spector, S. Tilles, D. Wallace, The diagnosis and management of anaphylaxis practice parameter: 2010 update, J Allergy Clin Immunol, 126 (2010) 477-480 e471-442.

[2] J.K. Lee, P. Vadas, Anaphylaxis: mechanisms and management, Clin Exp Allergy, 41 (2011) 923-938.

[3] Y. Makabe-Kobayashi, Y. Hori, T. Adachi, S. Ishigaki-Suzuki, Y. Kikuchi, Y. Kagaya, K. Shirato, A. Nagy, A. Ujike, T. Takai, T. Watanabe, H. Ohtsu, The control effect of histamine on body temperature and respiratory function in IgE-dependent systemic anaphylaxis, J Allergy Clin Immunol, 110 (2002) 298-303.

[4] D. Dombrowicz, V. Flamand, K.K. Brigman, B.H. Koller, J.P. Kinet, Abolition of anaphylaxis by targeted disruption of the high affinity immunoglobulin $E$ receptor alpha chain gene, Cell, 75 (1993) 969-976.

[5] S.G. Brown, S.F. Stone, D.M. Fatovich, S.A. Burrows, A. Holdgate, A. Celenza, A. Coulson, L. Hartnett, Y. Nagree, C. Cotterell, G.K. Isbister, Anaphylaxis: clinical patterns, mediator release, and severity, J Allergy Clin Immunol, 132 (2013) 1141-1149 e1145.

[6] M.E. Parsons, C.R. Ganellin, Histamine and its receptors, Br J Pharmacol, 147 Suppl 1 (2006) S127-135.

[7] M. Jutel, M. Akdis, C.A. Akdis, Histamine, histamine receptors and their role in immune pathology, Clin Exp Allergy, 39 (2009) 1786-1800.

[8] F.E. Simons, L.R. Ardusso, M.B. Bilo, Y.M. El-Gamal, D.K. Ledford, J. Ring, M. SanchezBorges, G.E. Senna, A. Sheikh, B.Y. Thong, World allergy organization guidelines for the assessment and management of anaphylaxis, World Allergy Organ J, 4 (2011) 13-37.

[9] A. Muraro, G. Roberts, M. Worm, M.B. Bilo, K. Brockow, M. Fernandez Rivas, A.F. Santos, Z.Q. Zolkipli, A. Bellou, K. Beyer, C. Bindslev-Jensen, V. Cardona, A.T. Clark, P. Demoly, A.E. Dubois, A. DunnGalvin, P. Eigenmann, S. Halken, L. Harada, G. Lack, M. Jutel, B. Niggemann, F. Rueff, F. Timmermans, B.J. Vlieg-Boerstra, T. Werfel, S. Dhami, S. Panesar, C.A. Akdis, A. Sheikh, Anaphylaxis: guidelines from the European Academy of Allergy and Clinical Immunology, Allergy, 69 (2014) 1026-1045.

[10] J. Ring, K. Messmer, Incidence and severity of anaphylactoid reactions to colloid volume substitutes, Lancet, 1 (1977) 466-469.

[11] R.Y. Lin, L.B. Schwartz, A. Curry, G.R. Pesola, R.J. Knight, H.S. Lee, L. Bakalchuk, C. Tenenbaum, R.E. Westfal, Histamine and tryptase levels in patients with acute allergic reactions: An emergency department-based study, J Allergy Clin Immunol, 106 (2000) 65-71.

[12] D. Laroche, M.C. Vergnaud, B. Sillard, H. Soufarapis, H. Bricard, Biochemical markers of anaphylactoid reactions to drugs. Comparison of plasma histamine and tryptase, Anesthesiology, 75 (1991) 945-949.

[13] D. Laroche, F. Dubois, J.L. Gerard, C. Lefrancois, B. Andre, M.C. Vergnaud, L. Dubus, H. Bricard, Radioimmunoassay for plasma histamine: a study of false positive and false negative values, Br J Anaesth, 74 (1995) 430-437. 
[14] P. McBride, D. Bradley, M. Kaliner, Evaluation of a radioimmunoassay for histamine measurement in biologic fluids, J Allergy Clin Immunol, 82 (1988) 638-646.

[15] M. Delaage, M. Darmon, A. Morel, [Histamine assay: use of a monoclonal antibody for radioimmunoassay and enzyme immunoassay], Allerg Immunol (Paris), 20 (1988) 333-335.

[16] J. Liu, L. Wang, W. Hu, X. Chen, D. Zhong, Development of a UHPLC-MS/MS method for the determination of plasma histamine in various mammalian species, J Chromatogr B Analyt Technol Biomed Life Sci, 971 (2014) 35-42.

[17] K.C. Chimalakonda, E. Pang, J.L. Weaver, K.E. Howard, V. Patel, M.T. Boyne, 2nd, Development and validation of a liquid-chromatography tandem mass spectrometry method to determine in vitro and in vivo histamine release, J Pharm Biomed Anal, 102 (2015) 494499.

[18] G.T. Laurichesse M, Moreau C, Tribut O, Tarte K, Morel I, Bendavid C, Amé-Thomas P Histamine quantification in human plasma using High Resolution Accurate Mass LC-MS technology, Clinical Biochemistry, Available online 14 August 2015 (2015).

[19] A. Morel, M. Darmon, M. Delaage, An immunoenzymoassay for histamine, Agents Actions, 30 (1990) 291-293.

[20] D. Laroche, P. Gomis, E. Gallimidi, J.M. Malinovsky, P.M. Mertes, Diagnostic value of histamine and tryptase concentrations in severe anaphylaxis with shock or cardiac arrest during anesthesia, Anesthesiology, 121 (2014) 272-279.

[21] M.G. Colazo, D.J. Ambrose, J.P. Kastelic, J.A. Small, Comparison of 2 enzyme immunoassays and a radioimmunoassay for measurement of progesterone concentrations in bovine plasma, skim milk, and whole milk, Can J Vet Res, 72 (2008) 32-36.

[22] C. Steenholdt, M.A. Ainsworth, M. Tovey, T.W. Klausen, O.O. Thomsen, J. Brynskov, K. Bendtzen, Comparison of techniques for monitoring infliximab and antibodies against infliximab in Crohn's disease, Ther Drug Monit, 35 (2013) 530-538.

[23] R. Yadav, K. Mohan, V. Kumar, M. Sarkar, K. Nitu, H.H. Meyer, B.S. Prakash, Development and validation of a sensitive enzyme immunoassay (EIA) for blood plasma cortisol in female cattle, buffaloes, and goats, Domest Anim Endocrinol, 45 (2013) 72-78. 


\section{FIGURE LEGENDS}

Figure 1: Correlation and Bland-Altman analyses for Immunotech ${ }^{\circledR}$ EIA versus RIA for the quantification of histamine concentration in plasma samples. (A) Scatter plot of HA concentrations of the 72 plasma samples measured with Immunotech ${ }^{\circledR}$ EIA and RIA, and associated Pearson's correlation coefficient r. (B) Bland-Altman plot for Immunotech ${ }^{\circledR}$ EIA versus RIA. Y axis: 100*(EIA-RIA) / average]; X axis: average $=($ EIA + RIA $) / 2$. (C) Scatter plot of HA concentrations of the 47 plasma samples presenting a concentration between 1 and $20 \mathrm{nM}$ by RIA, measured with Immunotech $^{\circledR}$ EIA and RIA, and associated Pearson's correlation coefficient $r$.

Figure 2: Correlation and Bland-Altman analyses for Demeditec Diagnostics ${ }^{\circledR}$ EIA versus RIA for the quantification of histamine concentration in plasma samples. (A) Scatter plot of HA concentrations of the 23 plasma samples measured with Demeditec EIA and RIA, and associated Pearson's correlation coefficient r. (B) Bland-Altman plot for Demeditec Diagnostics ${ }^{\circledR}$ EIA versus RIA. Y axis: $100 *$ (EIA-RIA) / average]; X axis: average $=(\mathrm{EIA}+\mathrm{RIA}) / 2$.

Figure 3: Correlation and Bland-Altman analyses for LC-HRMS versus RIA for the quantification of histamine concentration in plasma samples. (A) Scatter plot of HA concentrations of the 71 plasma samples measured with LC-HRMS and RIA, and associated Pearson's correlation coefficient r. (B) Bland-Altman plot for LC-HRMS versus RIA. Y axis: 100*( LC-HRMS-RIA) / average]; X axis: average $=($ EIA + RIA $) / 2$. (C) Scatter plot of HA concentrations of the 46 plasma samples presenting a concentration between 1 and $20 \mathrm{nM}$ by RIA, measured with LC-HRMS and RIA, and associated Pearson's correlation coefficient r.

Figure 4: Cut-off determination for the Immunotech ${ }^{\circledR}$ EIA and LC-HRMS method. Fifty-eight positive and 34 negative samples using a cut-off of $10 \mathrm{nM}$ of histamine measured by RIA were used to build the ROC curves. The black arrows point the best cut-off values: $14.39 \mathrm{nM}$ and $7.88 \mathrm{nM}$ were defined as the best cut-off values for Immunotech ${ }^{\circledR}$ EIA (A) and LC-HRMS (B), respectively. 
Figure 1

A

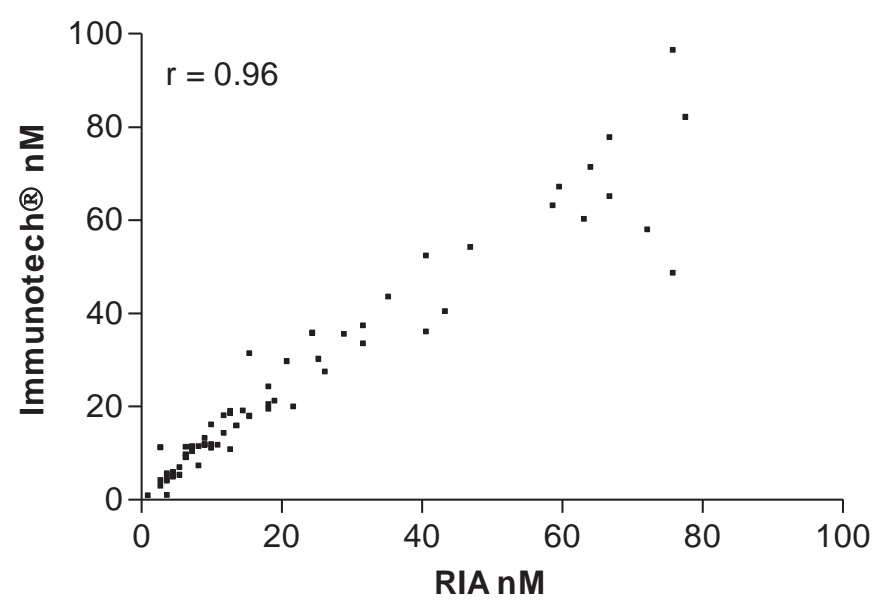

B

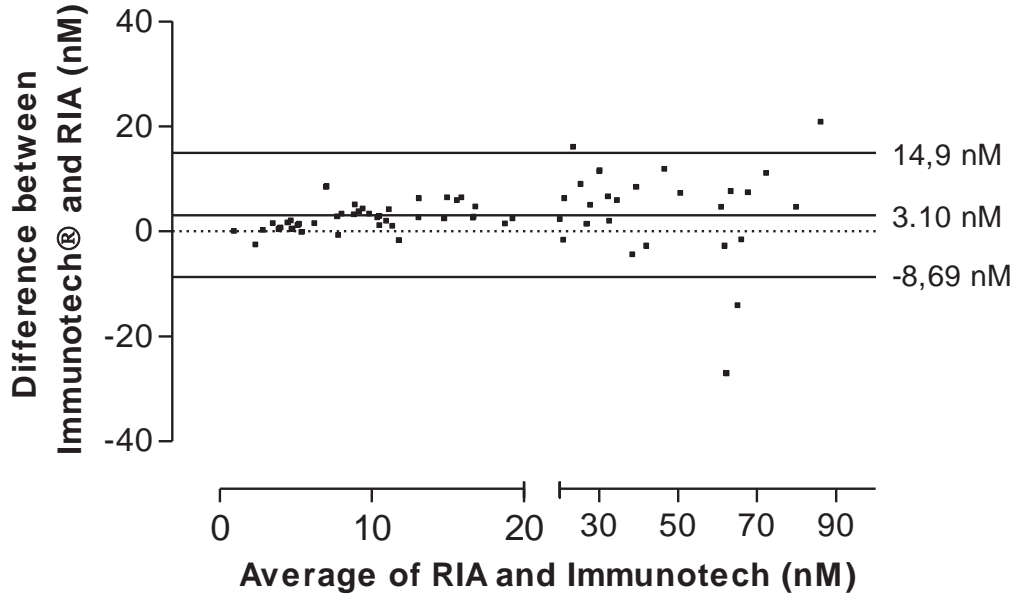

C

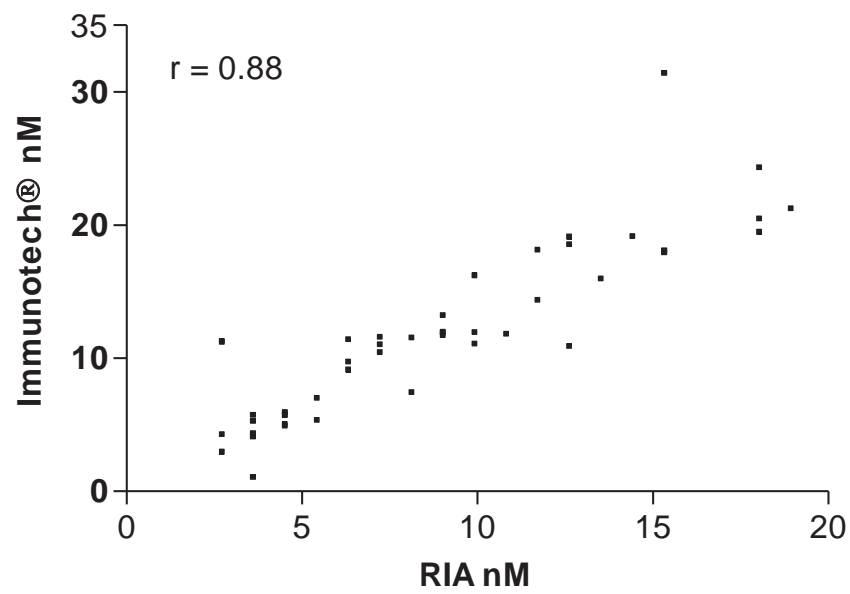


Figure 2

A

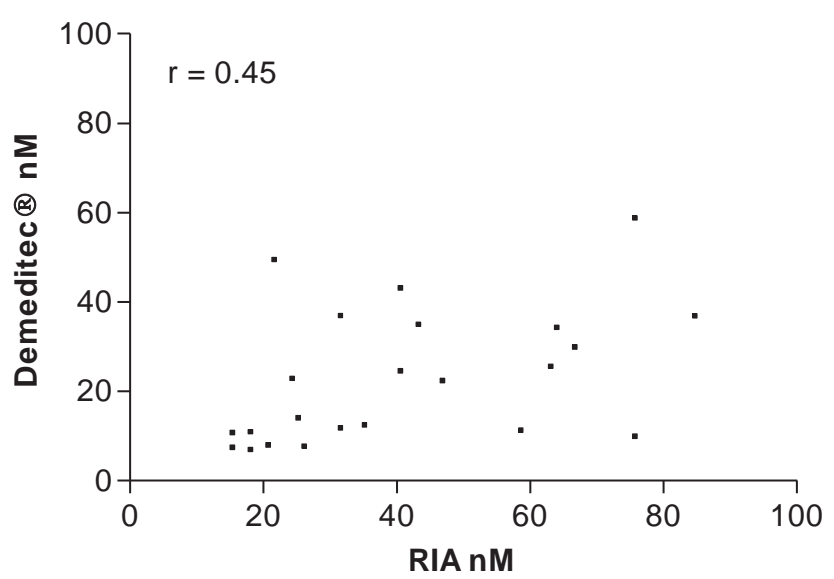

B

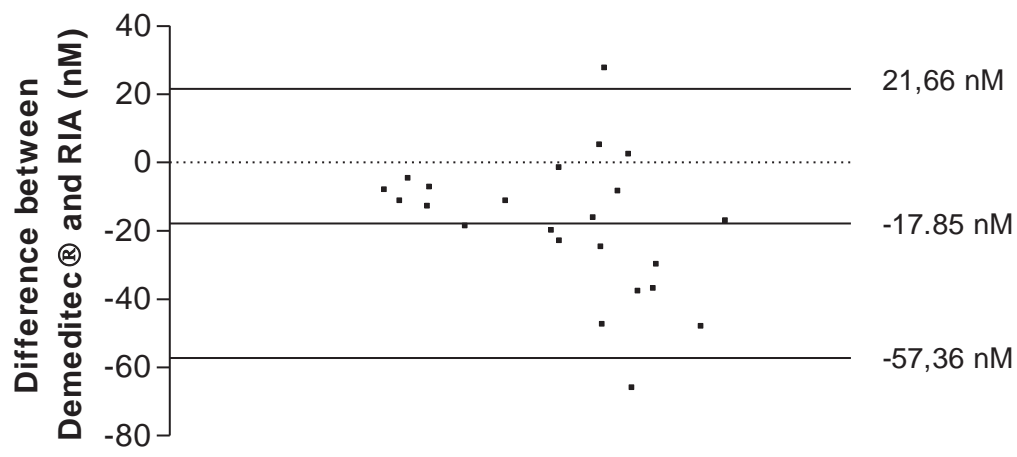

\begin{tabular}{lllllllll}
\hline & 5 & 10 & 15 & 2020 & 40 & 60 & 80 & 100
\end{tabular}

Average of RIA and Demeditec (nM) 
Figure 3

A

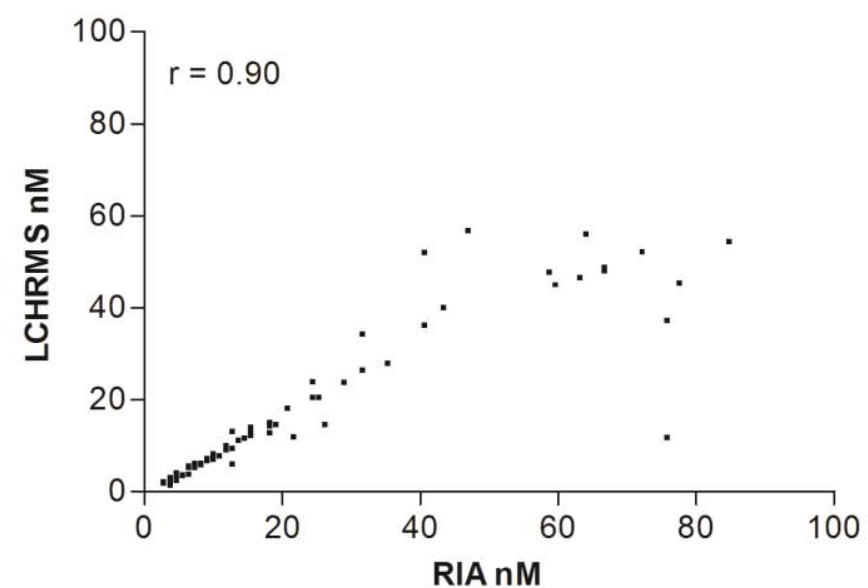

B

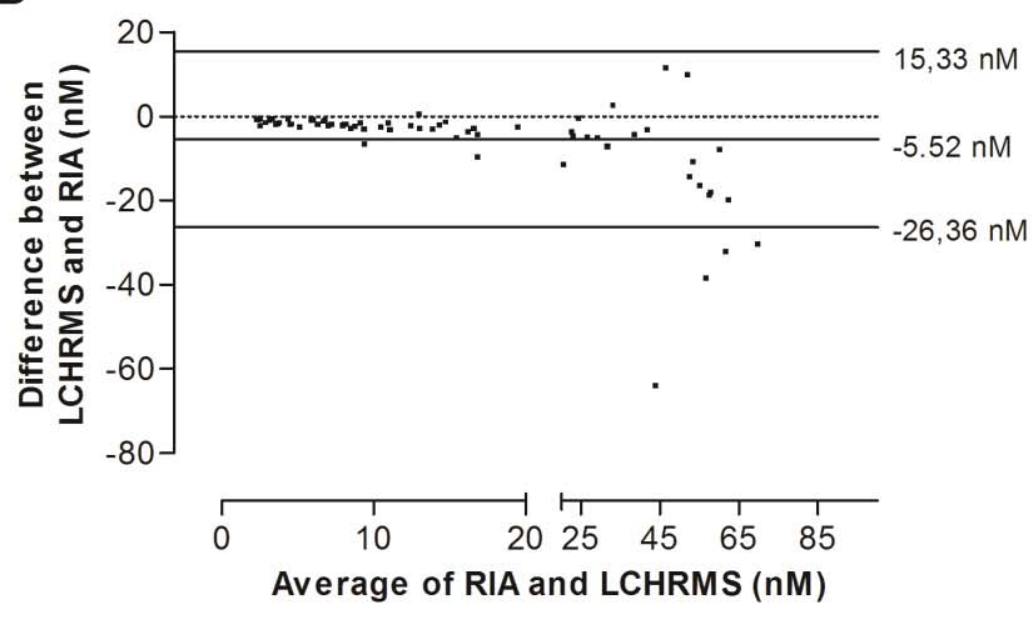

C

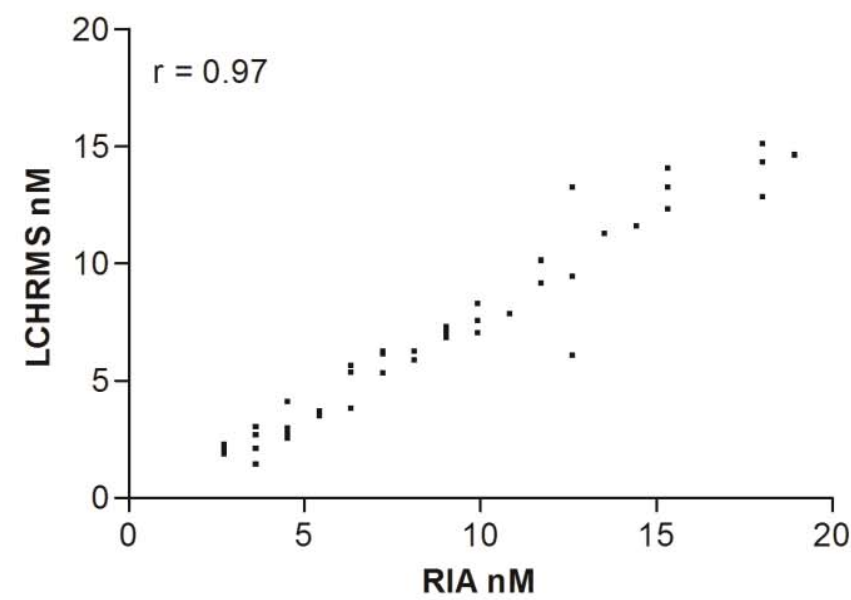


Figure 4
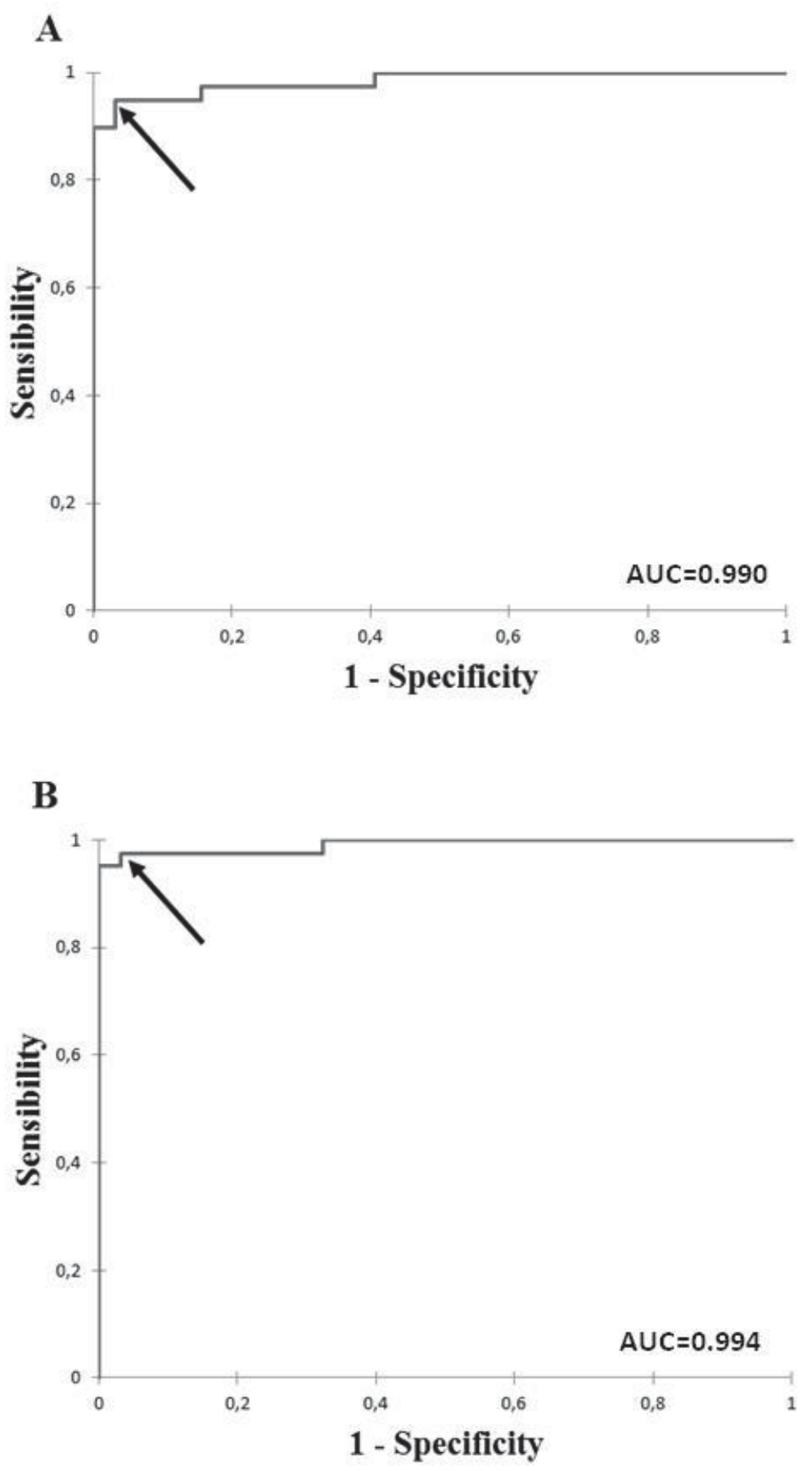
Table 1: comparison of HA quantification in plasma samples analyzed by Immunotech ${ }^{\circledR}$ and Demeditec Diagnostics ${ }^{\circledR}$ EIA, LC-HRMS and RIA. (PPV: Positive Predictive Value, NPV: Negative Predictive Value)

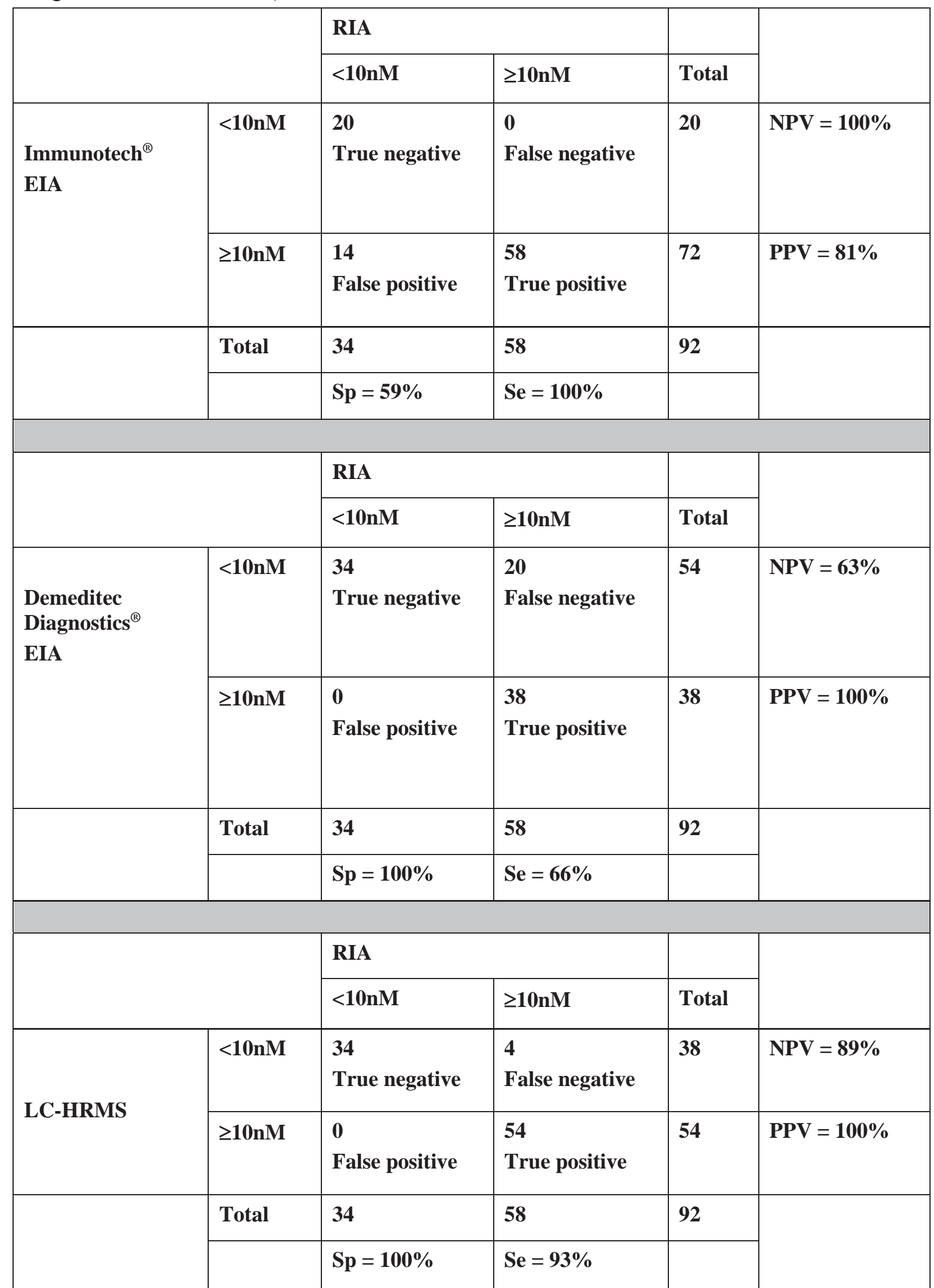


Table 2: Bias \pm SD and 95\% limits of agreement for HA quantification in plasma samples within the limits of detection of the methods, and focused on samples with a HA concentration measured by RIA comprised between 1 and 20nM.

\begin{tabular}{|l|l|l|}
\hline & Bias \pm SD & $\begin{array}{l}\mathbf{9 5 \%} \text { limits of } \\
\text { agreement }\end{array}$ \\
\hline Immunotech ${ }^{\circledR}$ EIA vs RIA & $3.10 \pm 6.02 \mathrm{nM}$ & $-8.69-14.90 \mathrm{nM}$ \\
\hline $\begin{array}{l}\text { Immunotech }{ }^{\circledR} \text { EIA vs RIA (1- } \\
\text { 20nM) }\end{array}$ & $2.97 \pm 3.08 \mathrm{nM}$ & $-3.07-9.01 \mathrm{nM}$ \\
\hline Demeditec ${ }^{\circledR}$ EIA vs RIA & $-17.85 \pm 20.16 \mathrm{nM}$ & $-57.36-21.66 \mathrm{nM}$ \\
\hline Demeditec ${ }^{\circledR}$ EIA vs RIA (1-20nM) & $-5.52 \pm 10.64 \mathrm{nM}$ & $-26.36-15.33 \mathrm{nM}$ \\
\hline LC-HRMS vs RIA & $-1.94 \pm 1.26 \mathrm{nM}$ & $-4.41-0.53 \mathrm{nM}$ \\
\hline LC-HRMS vs RIA (1-20nM) & & \\
\hline
\end{tabular}


Table 3: comparison of HA concentrations in plasma samples quantified by Immunotech $^{\circledR}$ EIA, LC-HRMS and RIA using optimized cut-offs. (PPV: Positive Predictive Value, NPV:

Negative Predictive Value)

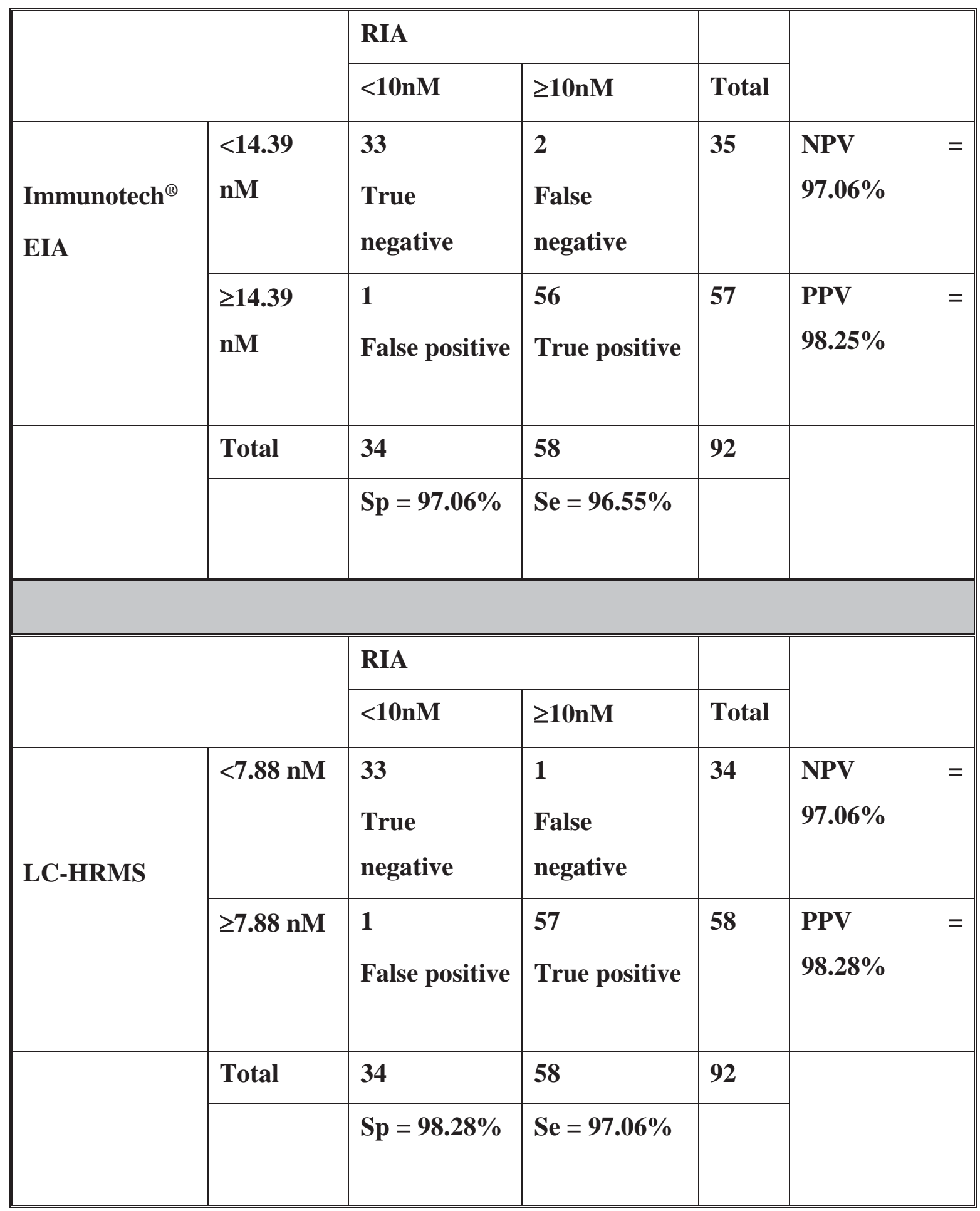

